\title{
Áttörésben visszamaradt bölcsességfogak ellátása az ambuláns szájsebészeti gyakorlatban egy év adatai alapján
}

\author{
DR. GYULAI-GAÁL SZABOLCS, DR. MINYA FANNI
}

\begin{abstract}
Az áttörésben visszamaradt fogak között a leggyakoribbak a bölcsességfogak, amelyek számos patológiás elváltozást, illetve orthodonciai problémát okozhatnak. Osztályunkon egy év alatt sebészi feltárással $1048 \mathrm{db}$ bölcsességfogat távolítottunk el, melyek közül 700 esetben részletes radiológiai elemzést és statisztikát készítettünk. A terápiás, preventív és orthodonciai okból eltávolított fogak száma közel megegyező volt, a terápiás indikációk közül leggyakoribb a pericoronitis és caries volt. A preventív és orthodonciai célú bölcsességfog-eltávolítás ideális ideje 16-23 éves kor, amikor még a gyökerek kevesebb mint 2/3-a fejlődött ki. Az esetek 20\%-ában ebben az időpontban történt a fogeltávolítás, ami a preventív szemlélet terjedését támasztja alá. Posztoperatív szövődmény az esetek 6\%-ában fordult elő, köztük leggyakoribb a hosszabb ideig fennálló duzzanat és fájdalom. Súlyosabb szövődmény, mint sebszétnyílás és idegsérülés csak 1-1 esetben történt. A posztoperatív szövődmények előfordulása preoperatív radiológiai kiértékeléssel minimalizálható, illetve nehezebb esetekben CBCT-felvétel készítése is javasolt.
\end{abstract}

Kulcsszavak: bölcsességfog, retenció, impakció, prevenció, röntgendiagnosztika

\section{Bevezetés}

A dento-alveoláris sebészetben az egyik leggyakoriabb ambuláns beavatkozás az áttörésben visszamaradt fogak eltávolítása. Az állcsontok méretének csökkenése, a fogív rövidülése miatt gyakori probléma, hogy nincs elég hely az állcsontban a fogaknak. Torlódás miatt bizonyos fogak egyáltalán nem mutatnak előtörési hajlamot, vagy beékelődnek és nem tudják elfoglalni helyüket a fogsorban, így részben vagy teljesen áttörésben visszamaradottak maradnak [25, 10]. Ezek közül a leggyakoribbak az alsó, majd a felső bölcsességfogak, ezeket követik a felső szemfogak [11, 12], a kisőrlők és a számfeletti mesiodensek.

A részben előtört bölcsességfogak gyakran okoznak problémát. A körülöttük lévő fog eredetü follicularis térbe ételmaradványok kerülnek és a felszaporodó baktériumok fájdalmas lágyrészgyulladást, pericoronitist okoznak [23]. A nehéz hozzáférés miatt általában kevésbé sikerül tisztán tartani ezeket a bölcsességfogakat, ami nemcsak a pericoronitisnek, hanem a cariesnek is kedvez. A retineált bölcsességfog további patológiás folyamatok forrása lehet, amelyek az előtte lévő moláris fogat is érinthetik $[3,8]$. A szomszédos moláris fog gyökérresorptiója is elöfordulhat [2].

A teljesen impaktált fogak körül kialakulhat follicularis cysta [30], ritkán odontogén tumor [29, 13], pl. ameloblastoma, ami állcsontduzzanatot és arcfájdalmakat okozhat. A bölcsességfogak, késői előtörésük során az előttük lévő fogakra kifejtett nyomással azok torlódását okozhatják [7, 26]. Emiatt gyakran nemcsak terápiás, hanem preventív és orthodonciai okkal is eltávolítjuk a bölcsességfogakat.

Vizsgálatainkat a Semmelweis Egyetem Orális Diagnosztikai Tanszék Dento-alveoláris Sebészeti Osztályán végeztük, ahol összesen $1048 \mathrm{db}$ bölcsességfog mütéti eltávolítása történt 2016. 12. 01. és 2017. 12. 31. között.

\section{Vizsgálati anyag és módszer}

A vizsgálatban 483 páciens vett részt, amely során összesen 700 bölcsességfog eltávolítást értékeltünk ki részletesen. A páciensek átlag életkora 25 év (1383 év). Egyetlen páciens sem került kizárásra általános sebészi kontraindikáció miatt [20]. Az anatómiai képletek sérülésének veszélye miatt 3 esetben döntöttünk a fog megtartása mellett, ami egyébként nem okozott panaszt.

A sebészi feltárás előtt minden esetben panorámafelvétel készült, szükség esetén, összesen 17-szer CBCTfelvétellel kiegészítve. A fogak formáját, helyzetét ezek alapján értékeltük és soroltuk nehézségi fokozatba a mütét megtervezéséhez.

Minden esetben sebészi feltárás történt, a hazai és nemzetközi útmutatással megegyező módon $[5,9,18]$. L-alakú mucoperiosteális lebeny képzésével, vagy sulcusban vezetett, segédmetszés nélküli lebennyel kerültek a fogak feltárásra [31]. Szükség esetén a környező csont eltávolítását és a fog darabolását követően a fogak eltávolítása fogóval vagy emelővel történt. A fog- 
zacskó maradványainak eltávolítása és sebtoilette után a lebenyt per primam zártuk, nem felszívódó varratokkal. A posztoperatív fájdalom és ödéma enyhítésére az irodalomban előfordul a per secundam sebzárás javallata, ennek ellenére a per primam zárást részesítjük előnyben, mert így könnyebb a pácienseknek a megfelelő szájhigiéniát fenntartani [21]. Minden páciens ugyanazon a rehabilitációs protokollon ment keresztül, antibiotikumot szedtek egy hétig (penicillin származékot vagy allergia esetén clindamicint), illetve szükség esetén NSAID fájdalomcsillapítót $[14,16]$. A varratszedés és a posztoperatív szövődmények értékelése a mútét után egy héttel történt.

\section{Eredmények}

Az esetek 2/3-ában alsó, 1/3-ában felső bölcsességfog került extractióra. A teljesen áttört fogak, melyeket az anatómiai adottságok miatt mútéti feltárással távolítottunk el, az összes eset $21 \%$-át képezték, a részben előtört fogak 31\%-ban, a teljesen impaktáltak 48\%-ban fordultak elö.

Az eltávolítás indikációja szempontjából az eseteket 3 csoportba soroltuk, melyek között nagyjából azonos arányban fordultak elő terápiás (39\%), orthodonciai (29\%) és preventív (32\%) műtétek. Preventív indikációnak azokat az eseteket tekintettük, amikor sem panasz nem volt, sem fogszabályozó kezelés nem történt. A terápiás csoporton belül a leggyakoribb indikáció a pericoronitis volt, melyet akut esetben annak súlyosságától függően rendszeres Clumsky-s gézcsíkozással vagy antibiotikummal kezeltünk és csak a gyulladás megszūnte után távolítottuk el a fogat. Caries és ebből adódó destrukció és gyulladásos folyamat volt a második leggyakoribb panasz, amely esetenként a 7-es fogat is érintette. Kisebb arányban volt az eltávolítás oka tasakképződés, ami a többi fog parodontitisével együtt volt jelen ismeretlen eredetű arcfájdalommal társulva. Gócbetegség 5, cysta follicularis 4, szomszédos moláris fog gyökérresorpciója 3, szájzár 2, odontoma 1 esetben fordult elő (1. kép).
A fogak tengelyállásának megoszlása: 41\%-ban verticalis, 34\%-ban mesioangularis és 25\%-ban vegyesen distoangularis, horizontális, illeve transversalis volt (2. kép).

A gyökerek 80\%-ban teljesen kifejlödtek, 15,5\%-ban kevesebb mint 2/3-uk fejlődött ki, 4,5\%-ban pedig még egyáltalán nem jelentek meg a gyökérnyúlványok. Germectomia 49 esetben (7,5\%) történt, mely a meg nem jelent vagy épp megjelent gyökérnyúlványú fogakat foglalja magába. A teljesen kifejlett gyökerű fogaknál azok formáját is vizsgáltuk: $44 \%$ kúpos, összetérő, $26 \%$ széttérő, $23 \%$ görbe és $7 \%$ apicálisan megvastagodott vagy görbült gyökérformát találtunk.

A fog előtörésének fokozatát vizsgálva közel azonos arányban találtunk mindhárom kategóriában fogakat [6]: 31\%-ban a bölcsességfog koronájának csúcsa elérte az occlusiós síkot, 38\%-ban az occlusiós sík és a szomszédos fog zománc-cement határa közt helyezkedett el, 31\%-ban pedig ez alatt.

Azt, hogy mennyi helye van a bölcsességfognak a fogívben és így mennyire lesz hozzáférhető a műtéti feltárás során, a második moláris fog distalis felszíne és a trigonum retromoláre szintjén a crista temporális közt mért távolsággal határoztuk meg [6]. Ez a távolság nagyobb vagy egyenlő volt a bölcsességfog mesiodistalis átmérőjével 23\%-ban, kisebb volt $69 \%$-ban, és $8 \%$-ban a crista temporalis egészen a 7-es fog distalis felszínéig húzódott.

Elemeztük a canalis mandibulae helyzetét az eltávolítandó foghoz viszonyítva. 83\%-ban a canalis mandibulae egyáltalán nem volt kontaktusban a foggal, 15\%ban közvetlenül a fog gyökere mellett futott buccalisan vagy lingualisan, és 1,8\%-ban, összesen 8 esetben haladt át a nervus alveolaris inferior a fog gyökerei közt, amit CBCT-felvételen állapítottunk meg.

A radiológiai értékelés alapján a fogakat nehézségi fok szerint 3 csoportba osztottuk [6]: 24\%-ban könnyú, $63 \%$-ban közepesen nehéz és 13\%-ban nehéz bölcsességfog-eltávolítást végeztünk egy év alatt.

Posztoperatív szövődmény az esetek 6\%-ában fordult elő. Ezek közt vezető helyen szerepelt az arcduzzanat $(3,6 \%)$ és a fájdalom $(1,3 \%)$, melyet az esetben

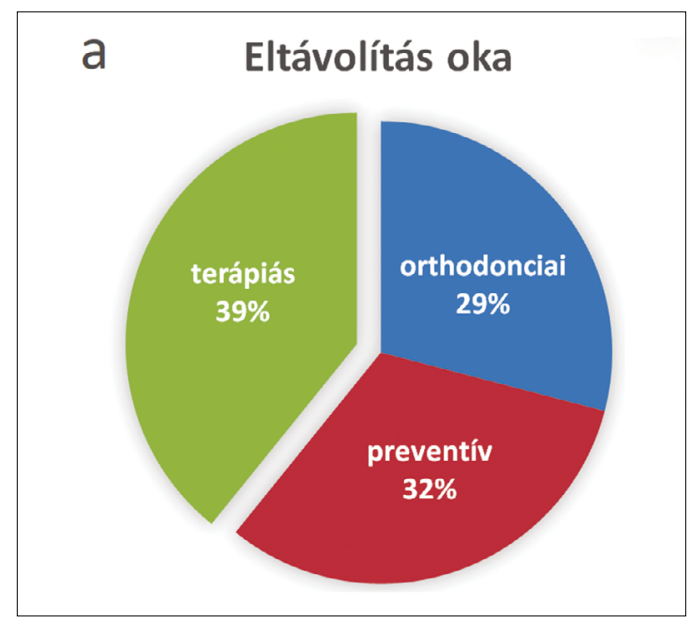

\section{b Terápiás indikációk}

- pericoronitis
- caries
- tasak
- fájdalom
góc
cysta follicularis
- 7-es resorptio
- szájzár
- odontoma

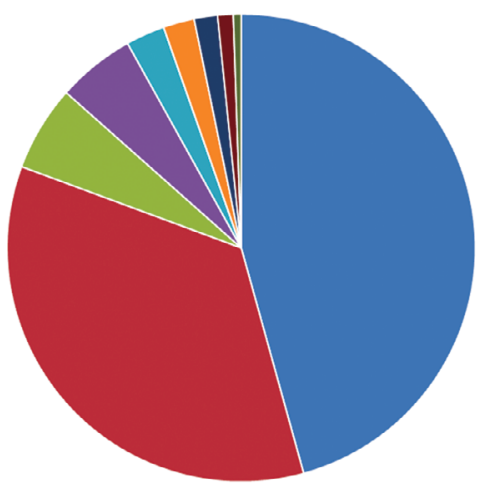

1. kép: a: A bölcsességfogak eltávolításának indikációi. $b$ : A terápiás indikációk típusai. 


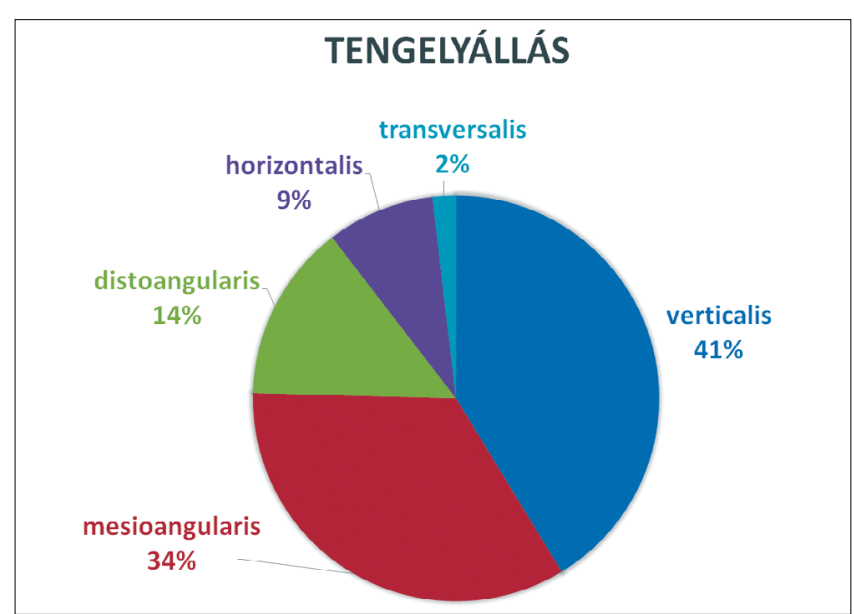

2. kép: A bölcsességfogak lehetséges tengelyállásainak előfordulási aránya.

Posztoperatív szövődmények - esetek 6\%-ában

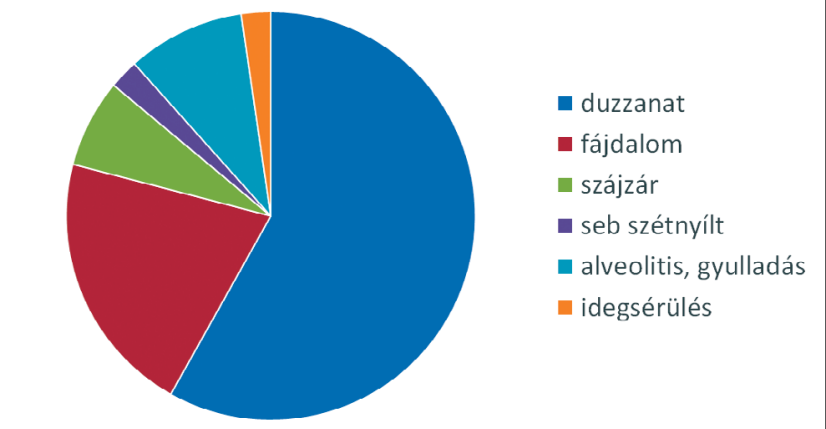

3. kép: Posztoperatív szövődmények

a bölcsességfogak sebészi eltávolítása után.

tekintettünk szövődménynek és nem a beavatkozás természetes velejárójának, ha az a mütét után egy héttel is fennállt. Elöfordult még alveolitis 4, szájzár 3 , seb szétnyílás és idegsérülés 1-1 esetben (3. kép). A szétnyílt seb kürettálás és Clumsky-s gézcsíkozás után per secundam gyógyult. A nervus mandibularis sérülése féloldali zsibbadásként jelentkezett egy olyan bölcsességfog eltávolítása után, mely mellett közvetlenül haladt el az ideg és luxálás közben megnyomódott. Néhány hét soft-lézer fizikoterápia és Milgamma szedése után az ideg regenerálódott [4, 22].

\section{Megbeszélés}

A preventív szemlélet és az állcsont-orthopédia elterjedésének köszönhetően a bölcsességfogak eltávolítása napjainkban egyenlő arányban terápiás, preventív és orthodonciai beavatkozás. Az általános fogorvos és orthodontus szakemberek egyre több pácienst küldenek szakrendelésünkre preventív fogeltávolítás céljából, illetve a fogszabályozó kezeléshez szükséges böl- csességfog-eltávolításra. Figyelemre méltó, hogy nemcsak a prevenciós indikáció aránya magas, hanem jelentős a teljesen impaktált fogak eltávolításának száma is a részben vagy tejesen elötörtekhez képest. Az ideális életkor a bölcsességfogak eltávolításához a 16 és 23 év közötti időszak, mikor már a gyökérnyúlványok megjelentek, de még kevesebb mint 2/3-uk fejlődött ki, így könnyebb eltávolítani és kisebb a posztoperatív szövődmények esélye (4. kép). A nálunk tapasztalt 25 éves átlagéletkor, a gyökerek átlagos fejlettségi szintje, valamint több hazai és nemzetközi cikk is a preventív szemlélet terjedését bizonyítja, fiatalabb korban kerülnek hozzánk a páciensek, mint amit a korábbi évek irodalma közölt [15, 17, 24].

A nemzetközi irodalom nem egységesen vélekedik a bölcsességfogakról, hogy azok okozhatnak-e torlódást vagy sem $[7,26]$. A mi klinikai megfigyelésünk, hogy ha nem történik fogszabályozó kezelés, a bölcsességfogak nem befolyásolják jelentősen a többi fog helyzetét. Azonban ha történt fogszabályozás, akkor a bölcsességfogak az előtörésük során az előttük lévő (korábban sorba állított) fogakra kifejtett nyomással a frontfogak torlódását okozhatják.

A posztoperatív szövődmények előfordulási aránya megegyezik a nemzetközileg közölt átlaggal [24]. A szövődmények minimalizálásához fontos a körültekintő diagnózis és a mútét gondos megtervezése, ezért legalább egy panorámaröntgen készítése és áttekintése

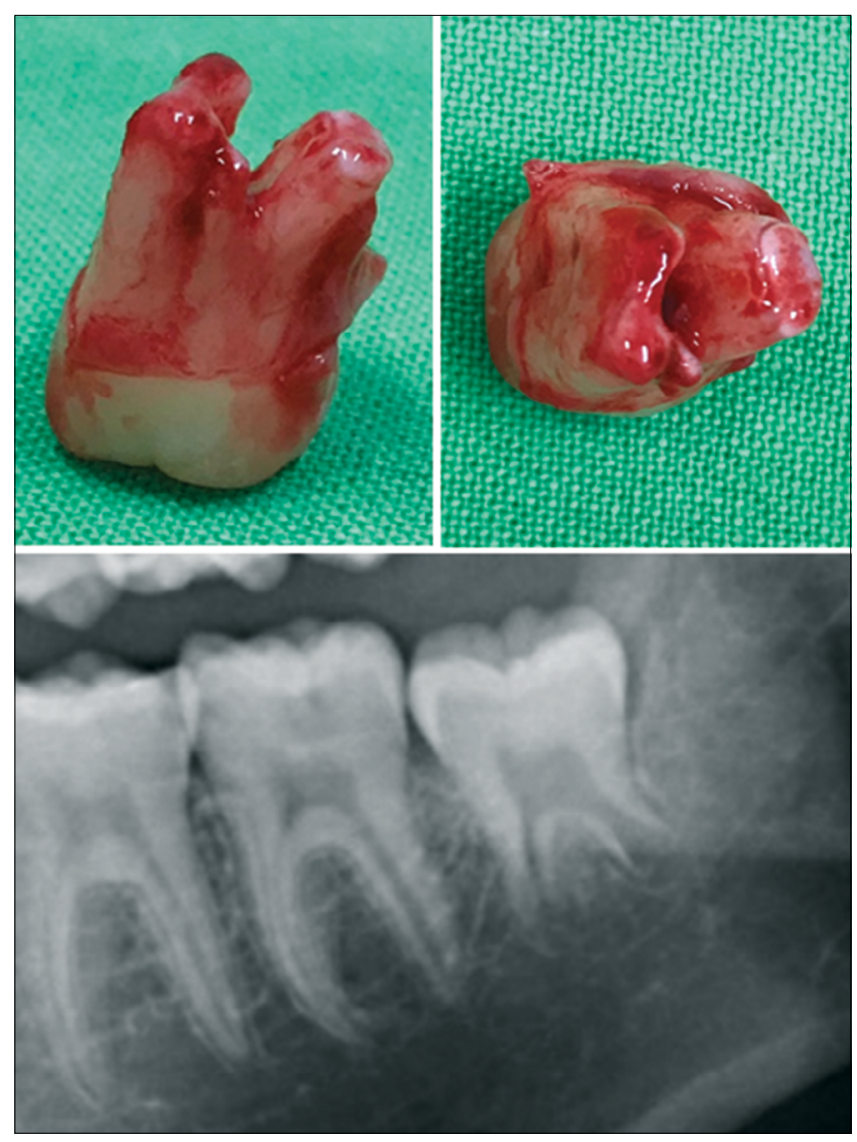

4. kép: Ideális gyökér-fejlettségi állapot a bölcsességfog eltávolításához:

a gyökérnyúlványok megjelentek, de 2/3-uknál kevesebb fejlődött ki. 
minden fogeltávolítás előtt szükséges. Az általunk megfigyelt bölcsességfogak tengelyállása és elhelyezkedése nem különbözik a korábban megfigyelt adatoktól [1]. A fogak canalis mandibulae-hez való viszonya az esetek nagy részében megállapítható a panoráma röntgenfelvételen, de ha rávetül a fog gyökere a canalis mandibulae-ra, célszerü CBCTfelvételt készíteni, mert azzal teljes biztonsággal eldönthető, hogy a nervus mandibularis a fog gyökerei közt halad át, vagy a fog mellett fut [27, 28]. Mivel ezzel az információval jó eséllyel elkerülhető az ideg sérülése, és a CBCT napjainkban már könnyen elérhető, elterjedt diagnosztikai eszközzé vált, ezért komplikált esetekben feltétlenül javasoljuk a CBCT használatát, melynek előnyeit számos publikáció is alátámasztja [19, 32].

\section{Irodalom}

1. Arora SS, Phull t, Kumar I, Kumar A, Kumar N, Singh H: A comparative study of the effect of two dosages of submucosal injection of dexamethasone on postoperative discomfort after third molar surgery: a prospective randomized study. Oral Maxillofac Surg. 2018; 22. (2): 225-230.

2. Camargo IB, Sobrinho JB, Andrade ES, Van Sickels JE: Correlational study of impacted and non-functional lower third molar position with occurrence of pathologies. Prog Orthod. 2016; 17. (1): 26.

3. Claudia A, Barbu hM, Adi L, Gultekin A, Reiser V, Gultekin P, MiJIRITSKY E: Relationship Between Third Mandibular Molar Angulation and Distal Cervical Caries in the Second Molar. J Craniofac Surg. 2018; Volume Publish Ahead of Print DOI: 10.1097/ SCS. 0000000000004505

4. de Oliveira RF, da Silva AC, Simões A, Youssef MN, de Freitas PM: Laser Therapy in the Treatment of Paresthesia: A Retrospective Study of 125 Clinical Cases. Photomed Laser Surg. 2015; 33. (8): 415-23.

5. SzABó Gy: Szájsebészet, maxillofacialis sebészet. (3rd ed.) Semmelweis Kiadó, Budapest, 2004; 59-68.

6. JoóB-FAnCSALY Á: A bölcsességfogak szerepe a fogászat különbözó szakterületein. Semmelweis Kiadó, Budapest, 2010; 81-104.

7. Genest-Beucher S, Graillon N, Bruneau S, Benzaquen M, Guyot L: Does mandibular third molar have an impact on dental mandibular anterior crowding? A literature review. J Stomatol Oral Maxillofac Surg. 2018; 119. (3): 204-207.

8. Glória JCR, Martins CC, Armond ACV, Galvão El, Dos Santos CRR, FALCI SGM: Third Molar and Their Relationship with Caries on the Distal Surface of Second Molar: A Meta-analysis. J Maxillofac Oral Surg. 2018; 17. (2): 129-141.

9. Miloro M, Ghal Ge, Larsen PE, Waite PD: Peterson's principles of oral and maxillofacial surgery. (2nd ed.) Hamilton, Ontario, 2004; 139-156.

10. Gyulai-Gá́l S, Joób-Fancsaly Á, Hrusztics A, Pataky L, Szücs A: $A z$ áttörésükben visszamaradt fogak előtörését akadályozó tényezők (Esetismertetés). Fogorvosi szemle, 2003; 96. (4): 155-159.

11. Gyulai-Gaál S, Mihályı S, Martonffy K, Suba Z: A felső szemfog retenció etiológiája és diagnosztikája. Fogorvosi szemle, 2010; 103. (2): 49-52.

12. Gyulai-GaÁl $S$, Mihályı $S$, SuBA Z: Az áttörésben visszamaradt felső szemfogak szájsebészeti-orthodonciai ellátása. Fogorvosi szemle, 2010; 103. (4): 119-123.

13. Gyulai-GaÁl $S$, Takács D, Barabás J, Tarján I, Martonffy K, Szabó G, SuBA Z: Fogelőtörési zavarokkal járó vegyes odontogén daganatok. Fogorvosi szemle, 2007; 100. (2): 65-69.

14. Isiordia-Espinoza MA, Bologna-Molina RE, Hernández-Miramontes Ya Zapata-Morales JR, Alonso-Castro AJ, Martínez-Morales $\mathrm{F}$, et al.:
Pharmacological Control of Complications Following to Third Molar Removal: Evidence Based on A Meta-Analysis. Drug Res (Stuttg). 2018; Volume Pulish Ahead of Print DOI: 10.1055/a0637-8948

15. Kaposvári I, Körmöczi K, Horváth $F$, Buglyó A, Tural AR, JoóbFANCSALY Á: Az alsó bölcsességfogak műtéti eltávolítását követő késői posztoperatív gyulladás (delayed-onset infection) vizsgálata. Orvosi Hetilap, 2018; 159. (31): 1278-1283.

16. Kaposvári I, KörmöczI K, László Zs, Oberna F, Horváth F, JoóbFANCSALY Á: A preoperatív antibiotikus és antiszeptikus kezelés hatása mútéti úton eltávolított alsó bölcsességfog sebgyógyulására: prospektív randomizált vizsgálat. Orvosi Hetilap, 2017; 158. (1): $11-17$.

17. Kautto A, VehKalahti MM, Ventä I: Age of patient at the extraction of the third molar. Int J Oral Maxillofac Surg. 2018; 47. (7): 947-951.

18. KRÜGER E: Farbatlas der dento-alveolären Chirurgie. Heidelberg, Hüthig, 1997; 78-108.

19. Luo Q, Diao W, Luo L, Zhang Y: Comparisons of the Computed Tomographic Scan and Panoramic Radiography Before Mandibular Third Molar Extraction Surgery. Med Sci Monit. 2018; 24: 3340-3347.

20. Nagy R, Szabó K, Szücs A, Ruszin T, Joób-Fancsaly Á: A rheumatoid arthritis hatása a szájsebészeti és implantológiai ellátásban a szakirodalom alapján. Fogorvosi szemle, 2017; 110. (1): 3-6.

21. PACHIPULUSU PK, S M: Comparative study of primary and secondary closure of the surgical wound after removal of impacted mandibular third molars. Oral Maxillofac Surg. 2018; 22. (3): 261-266.

22. Pol R, Gallesio G, Riso M, Ruggiero T, Scarano A, MortellaRo C, Mozzatı M: Effects of Superpulsed, Low-Level Laser Therapy on Neurosensory Recovery of the Inferior Alveolar Nerve. J Craniofac Surg. 2016; 27. (5): 1215-1219.

23. Sarode GS, Sarode SC, Prajapati G, Maralingannavar M, Patil S: Calcifying Cystic Odontogenic Tumor in Radiologically Normal Dental Follicular Space of Mandibular Third Molars: Report of Two Cases. Clin Pract. 2017; 7. (1): 933.

24. Sigron GR, Pourmand PP, Mache B, Stadlinger B, Locher MC: The most common complications after wisdom-tooth removal: part 1: a retrospective study of 1,199 cases in the mandible. Swiss Dent J. 2014; 124. (10): 1042-1046.

25. Singh N, Chaudhari S, Chaudhari R, Nagare S, Kulkarni A, ParkarWAR P: A radiographic survey of agenesis of the third molar: A panoramic study. J Forensic Dent Sci. 2017; 9. (3): 130-134.

26. Stanaityte R, Trakiniené $\mathrm{G}$, Gervickas A: Do wisdom teeth induce lower anterior teeth crowding? A systematic literature review. Stomatologija 2014; 16 (1): 15-18.

27. Szalma J, Lempel E, Csuta T, Bártfai D, Jeges S, Olasz L: A panorámaröntgen szerepe a nervus alveolaris inferior sérülésének várható kockázatában alsó bölcsességfogak eltávolítása előtt. A gyökérgörbület és a gyökércsúcs-canalis mandibulae átfedésének hatása a rizikóbecslésre. Fogorvosi szemle, 2010; 103. (2): 43-47.

28. Szalma J, Lempel E, Csuta T, Vajta L, Jeges S, Olasz l: A jellegzetes panorámaröntgen-jelek szerepe a nervus alveolaris inferior sérülésének várható megítélésében alsó bölcsességfogak eltávolításakor. Fogrovosi szemle, 2011; 104. (1): 27-33.

29. Tarján I, Gyulal-Gá́l S, Soós A, Rózsa N: Tuberculate and Odontoma Type Supernumerary Teeth. J Craniofac Surg. 2005; 16. (69): 1098-1102.

30. Tóth M, Barta A, Suba Z, Mihályı S: Cysta follicularis a vegyes fogazatban. Fogorvosi szemle, 2012; 105. (4): 147-151.

31. VÉCSEY Zs, JoóB-FANCSALY Á: Alsó impactált bölcsességfogak eltávolítása utáni parodontális állapotok vizsgálata, két lebenytechnika öszszehasonlító elemzése. Fogorvosi Szemle, 2012; 105. (1): 29-33.

32. Wang D, Lin T, Wang Y, Sun C, Yang L, Jiang H, Cheng J: Radiographic features of anatomic relationship between impacted third molar and inferior alveolar canal on coronal CBCT images: risk factors for nerve injury after tooth extraction. Arch Med Sci. 2018; 14. (3): 532-540. 


\section{Gyulal-Gá́l S, MinYA F}

\section{Treatment of impacted third molars in dento-alveolar surgery due to one year analysis records}

Wisdom teeth are the most commonly impacted teeth that can cause pathological lesions and orthodontic problems. In one year 1048 surgical wisdom teeth removal were performed in our department of which 700 cases were radiologically and statistically analyzed. $2 / 3$ of the wisdom teeth were removed from the mandible and $1 / 3$ from the maxilla. $21 \%$, of teeth were completely and $31 \%$ partially erupted while $48 \%$ were fully impacted. The percentage of the therapeutic, preventive and orthodontic indications were almost equal. Pericoronitis and caries were the most common therapeutic indications for surgical extraction. Less common indications were periodontal pocket formation, focal infection, follicular cyst, root resorption of adjacent teeth, trismus and odontoma. The ideal age for preventive and orthodontic wisdom teeth removal is between 16 and 23 when less than $2 / 3$ of the roots have formed. $20 \%$ of the removals in our department were performed within the above age range which demonstrates the spreading of our approach in everyday practice. During the radiological assessment the angulation and root formation of the wisdom teeth, depth of impaction, distance from the distal site of second molar to the ramus mandible and the relationship of the wisdom teeth to the canalis mandible were observed. Postoperative complications, such as prolonged swelling and pain, occurred only in $6 \%$ of the cases. There was only one wound dehiscence and one mandibular nerve damage among the total number of cases. Preoperative radiological assessment and CBCT examination in complicated cases are recommended to reduce postoperative complications.

Keywords: wisdom tooth, retention, impaction, prevention, radiological assessment 